\author{
Asian Journal of Economic Modelling \\ $\operatorname{ISSN}(e): \quad 2312-3656$ \\ $\operatorname{ISSN}(p): \quad 2313-2884$ \\ DOI: $10.18488 /$ journal.8.2014.22.85.92 \\ Vol. 2, No. 2, 85-92 \\ (C) 2014 AESS Publications. All Rights Reserved. \\ URL: wwrw.aessweb.com
}

\title{
ESTIMATING THE RELATIVE IMPACTS OF HEALTH AND EDUCATION ON ECONOMIC DEVELOPMENT IN SOUTHERN AFRICA \\ .
}

\section{Elvis \\ Munyaradzi \\ Ganyaupfu}

\section{Keywords}

Economic development

Health, Education

Productivity

GNI per capita

Panel data.
Economic Research Division, Maxima Research Analytics, South Africa.

\begin{abstract}
This paper analysed the relative impacts of health and education on economic development in Southern Africa. A set of cross country panel data from 11 countries over the period 2005 - 2011 was used in the study. The econometric procedure adopted in the analysis followed the Breusch and Pagan Lagrangian Multiplier test and Hausman test techniques. Based on the Fixed Effects (FE) model, results show that health and education have significant positive effects on economic development; with health having a more remarkable effect on development in the region. The R-squared statistic indicates that nearly 21.79 percent total variation in economic development was accounted for by health and education during the period under review. The $\mathrm{F}(2,64)$ statistic $(=15.45 ; \mathrm{p}<0.05)$ reveals significance of the model; while the interclass correlation value shows that nearly 99.53 percent of the variance was due to differences across panels.
\end{abstract}

Contribution/ Originality: This study originates useful policy insights on the relative impacts of health and education on economic development in context of developing economies at regional level. Empirical evidence from the Southern African region signifies that health demonstrates a more pronounced significant positive effect in stimulating economic development comparative to education.

\section{INTRODUCTION}

According to the World Health Organisation (2002), a healthy population is an effective instrument for increased economic productivity. Bhargava et al. (2001) elaborates that economic development prospects of countries are significantly enhanced by improvements in health of the 
citizens. Better health conditions; measured by indicators such as infant and child mortality rates, life expectancy at birth and burden of disease, reflect improvements in quality of life. In developing countries, average life expectancy revealed remarkable gains from only 40 years in 1950 to 63 years by 1990 (World Bank, 1993). Factors such as improved nutrition, better sanitation, innovations in medical technologies and public health infrastructure have steadily increased human life span. The sustained effect of improved nutrition and medical care is the increased likelihood for children to survive longer into adulthood. Improvements in child survival further lead to decline in high fertility (Stark and Rosenzweig, 2006).

Similarly, education equips individuals with improved knowledge, skills and productive capabilities that stimulate economic development (Quang, 2012). From the human capital theoretical framework, education is regarded as an investment process that generates future flows of income. The costs incurred and the potential income sacrificed during the education process are compensated when the knowledge and competencies accumulated during the learning period generate sufficiently high rate of returns and raise the future flows of income to levels high enough to compensate for all costs incurred.

The objective of this paper was to estimate the relative impacts of health and education on economic development in the Southern African region using panel data. The paper proceeds as follows: Section 2 reviews literature on the individual effects of health and education on economic development. Section 3 specifies the econometric methodology and estimation procedure employed in the study. Section 4 presents, analyses and discusses the empirical findings; while Section 5 provides conclusions and recommendations for further studies.

\section{LITERATURE REVIEW}

Feinstein et al. (2006) regard human capital formation as a process that involves interaction between health and education. Bloom and Canning (2000) indicate that healthy and educated individuals are more efficient at assimilating knowledge and achieving higher productivity levels towards promotion of economic development. According to the World Health Organisation (2003), health generally refers to a state of complete physical, mental and social well-being rather than merely the absence of disease or infirmity. Jacobs and Rapaport (2002) accentuate use of life expectancy as a survival indicator that highlights the duration of an individual's implicit wellbeing. Bhargava et al. (2001) report significant positive effects of adult survival rates on economic development in low-income countries. The findings are in conformity with the life cycle models that explain how health determines income, wealth and consumption (Lilliard and Weiss, 1997; Smith, 1999).

Using life expectancy and mortality rates as health indicators, Mayer (2001) found that health accounted for approximately one third of long-term economic growth in Mexico during the period 1970-1995. Therefore, improved health; captured by life expectancy and infant mortality, demonstrates a significant positive impact on economic development. Empirical studies that have reported similar findings include Arora (2001), Gallup and Sachs (2001), Bloom et al. (2004), Fogel (2004), Bloom and Canning (2005) and Alsan et al. (2006). However, Acemoglu and Johnson (2006) found a small negative link from health to economic development. Although some 
variation exists, but substantial macro evidence to date provide reasonable basis to accept that improvements in health significantly and positively contribute towards economic development (DSAED, 2010).

From the total factor productivity perspective, research studies by Arora (2001), Mayer (2001); Bhargava et al. (2001), Bloom et al. (2004), Fogel (2004), Malik (2006), Bloom and Canning (2005), Weil (2006), and Bloom and Canning (2008) indicate that health; as captured by life expectancy at birth, significantly and positively affect total factor productivity, hence economic development. Findings of such studies are consistent with the studies by Alemu et al. (2005) and Kumar and Kober (2012); who observe that health significantly and positively affects total factor productivity. Moreover, another recent study by Saha (2013) analyzes the impact of health on factor productivity in the Indian economy. The study confirms that improvement of health conditions; as measured by the life expectancy at birth, affects total factor productivity growth positively and significantly.

From the educational dimension, considerable studies that analysed the effect of education on growth based on the growth accounting framework indicate positive links between the average years of schooling and economic growth. Following Barro and Lee (2010), the average years of educational attainment at secondary and tertiary levels have significant positive effects on economic growth. Using the enrolment rate as an indicator of education, Stevens and Weale (2003) indicate that an increase in enrolment rate by 1 percent leads to an increase in GDP per capita by nearly 0.35 percent in Europe. The results conform to Quang (2012) who asserts that education equips individuals with productive capabilities that stimulate economic development.

Nonetheless, it is worthwhile to understand the interaction between health and education. From the health side, investments in education critically depend on survival probabilities. Therefore, improved health enhances school attendance and mean years of schooling. Similarly, education offers individuals with knowledge to adopt health-seeking behaviour. However, although it remains unclear as to whether health is most improved by health-specific or general education, it is clear that interactions between education and health promote development spirals.

\section{METHODOLOGY}

This section addresses data and econometric procedure applied for estimation in this study.

\subsection{Data}

Cross-country panel data on health, education and income for 11 countries during the period 2005-2011 was used for the analysis. Data was collected from the UNDP's Human Development Report Office (HDRO) 2012 online database. Health index was used as a proxy for health; calculated based on life expectancy at birth expressed as an index using a minimum value of 20 years observed maximum value over 1980-2010. Similarly, education index was used as a proxy for education; calculated based on the mean years of schooling of adults and expected years of schooling of children. Income index was used as a proxy for GNI per income growth and indicator of economic development; calculated as GNI per capita in purchasing power parity 
terms expressed as an index using minimum value of $\$ 100$ and observed maximum value over 1980-2011.

\subsection{Estimation Procedure}

The procedure followed in selection of the appropriate estimation model was based on evaluation of the Pooled OLS regression, GLS Random Effects (RE) model and Fixed Effects (FE) model using the Breusch-Pagan Lagrangian Multiplier test and Hausman test techniques.

PooledOLSmodel : $Y_{i t}=\alpha+X_{i t}^{\prime} \beta\left(\alpha_{i}-\alpha+e_{i t}\right)$

Random Effects (RE) mode $1: Y_{i t}=\alpha+X_{i t}^{\prime} \beta+\left(u_{i}+v_{i t}\right) ; v_{i t} \sim I I D\left(0, \sigma_{v}^{2}\right)$

Fixed Effects(FE) model: $Y_{I i t}=\alpha_{i}+X_{i t}^{\prime} \beta+u_{i}+e_{i t}$

The Breusch and Pagan Lagrangian Multiplier test was run on the RE model to choose between the Pooled OLS model and RE model. The LM test was run based on the formulation:

$$
L M_{u}=\frac{n T}{2(T-1)}\left[\frac{\sum\left(\sum e_{i t}\right)^{2}}{\sum \sum e_{i t}^{2}}-1\right]^{2}=\frac{n T}{n(T-1)}\left[\frac{\sum(T) \bar{e}_{i}}{\sum \sum e_{i t}^{2}}-1\right] \sim \chi^{2}(1)
$$

Following rejection of the hypothesis that Pooled OLS was appropriate (Table 2), the Hausman test was run to choose between the RE model and FE model based on the specification:

$$
H=\left(\hat{\beta}_{F E}-\hat{\beta}_{R E}\right)^{\prime}\left[\left(V\left(\hat{\beta}_{F E}\right)-V\left(\hat{\beta}_{R E}\right)^{\wedge}(-1)\right]\left(\hat{\beta}_{F E}-\hat{\beta}_{R E}\right)\right.
$$

The Hausman test results were used to select the appropriate model between RE and FE at $5 \%$ level of significance. Differences across panels were measured by the interclass correlation $(\rho)$; which approaches 1 if the respective individual effects dominates the idiosyncratic error.

\subsection{Econometric Model}

The econometric estimation method used was a single equation model formulated as:

$$
\text { Incomepercapita_growth } h_{t}=\alpha+\beta_{1}\left(\text { Health }_{t}\right)+\beta_{2}(\text { Education })+u_{i t}
$$

\section{RESULTS AND DISCUSSION}

This section provides a discussion of the results obtained from the estimation conducted.

\subsection{Breusch and Pagan Lagrangian Multiplier (LM) Test}

The Breusch and Pagan LM test was applied on the RE model estimates (Table 1) to test whether Pooled OLS regression was the appropriate model to apply for analysis. The Hausman test results implied rejection of the null hypothesis that the Random Effects model was 
appropriate; indicating that the differences between the $\mathrm{FE}$ model and the $\mathrm{RE}$ model were systematic. Therefore, the coefficient estimates of the FE model were efficient.

Based on the results of the FE model, both health and education demonstrate significant positive effects on economic development in the region. In relative terms, health has a more pronounced effect on economic development than education. A $1 \%$ improvement in health status leads to approximately $0.28 \%$ increase in economic development. Similarly, a $1 \%$ increase in mean years of schooling leads to nearly $0.04 \%$ increase in economic development in the region.

Table-1. GLS Random Effects results

\begin{tabular}{|c|c|c|c|c|c|c|}
\hline \multicolumn{3}{|c|}{$\begin{aligned} \text { R-squared: within } & =0.3254 \\
\text { between } & =0.2377 \\
\text { overall } & =0.2249 \\
\text { corr }(\text { u_i,x } & =0(\text { assumed })\end{aligned}$} & $\begin{array}{l}30.61 \\
0.000 \\
\end{array}$ & $\begin{array}{l}\text { Wa } \\
\text { Pro }\end{array}$ & $\begin{array}{l}\operatorname{chi} 2(2) \\
>\operatorname{chi} 2\end{array}$ & $\begin{array}{r}: \min =7 \\
: \operatorname{avg}=7.0 \\
: \max =7 \\
= \\
=\end{array}$ \\
\hline $\begin{array}{ll}\text { Income } & \text { per } \\
\text { capita_growth }\end{array}$ & Coeff. & Std. Err. & $\mathbf{Z}$ & $P>|z|$ & 95\% Con & terval \\
\hline $\begin{array}{l}\text { Health } \\
\text { Education } \\
\text { _cons }\end{array}$ & $\begin{array}{l}.2859859 \\
.0460951 \\
.2931434\end{array}$ & $\begin{array}{l}.0589003 \\
.0217578 \\
.0502976\end{array}$ & $\begin{array}{l}4.86 \\
2.12 \\
5.83\end{array}$ & $\begin{array}{l}0.000 \\
0.034 \\
0.000\end{array}$ & $\begin{array}{l}.1705435 \\
.0034507 \\
.1945618\end{array}$ & $\begin{array}{l}.4014284 \\
.0887396 \\
.3917249\end{array}$ \\
\hline $\begin{array}{l}\text { sigma_u } \\
\text { sigma_e } \\
\text { rho }\end{array}$ & $\begin{array}{l}.13037441 \\
.01101262 \\
.99291551\end{array}$ & & & & & \\
\hline
\end{tabular}

The Breusch and Pagan Lagrangian Multiplier test for random effects results Table 2 rejected the null hypothesis that the Pooled OLS model was appropriate.

Table-2. Breusch and Pagan Lagrangian Multiplier test for Random Effects results

\begin{tabular}{l|l|l}
\hline & Var & sd = sqrt(Var) \\
\hline Income per capita_growth & .0267519 & .16356 \\
$\mathrm{e}$ & .0001213 & .0110126 \\
$\mathrm{u}$ & .0169975 & .1303744 \\
\hline Test: $\operatorname{Var}(\mathrm{u})=0$ & Chibar2(01)=169.70 & Prob $>$ chibar2 $=0.0000$ \\
\hline
\end{tabular}

Table-3. Fixed Effects results

\begin{tabular}{|c|c|c|c|c|c|c|}
\hline \multicolumn{3}{|l|}{$\begin{aligned} \text { R-squared: within } & =0.3256 \\
\text { between } & =0.2300 \\
\text { overall } & =0.2179 \\
\text { corr }(\text { u_i, Xb) } & =0.3528\end{aligned}$} & \multicolumn{4}{|c|}{$\begin{array}{l}\text { obs per group: } \min =7 \\
: \text { avg }=7.0 \\
: \max =7 \\
F(2,64) \quad=15.45 \\
\text { Prob }>\mathrm{F} \quad=0.0000\end{array}$} \\
\hline Income per capita_growth & Coeff. & Std. Err. & $\mathbf{z}$ & $\mathbf{P}>|\mathbf{z}|$ & 95\% Conf & nterval \\
\hline $\begin{array}{l}\text { Health } \\
\text { Education } \\
\text { _cons }\end{array}$ & $\begin{array}{l}.2823343 \\
.0426238 \\
.2966841 \\
\end{array}$ & $\begin{array}{l}.0572114 \\
.0210815 \\
.0287714\end{array}$ & $\begin{array}{l}4.93 \\
2.02 \\
10.31\end{array}$ & $\begin{array}{l}0.000 \\
0.047 \\
0.000\end{array}$ & $\begin{array}{l}.1680415 \\
.0005087 \\
.2392067 \\
\end{array}$ & $\begin{array}{l}.3966271 \\
.0847389 \\
.3541616 \\
\end{array}$ \\
\hline $\begin{array}{l}\text { sigma_u } \\
\text { sigma_e } \\
\text { rho }\end{array}$ & $\begin{array}{l}.16068139 \\
.01101262 \\
.99532464 \\
\end{array}$ & & & & & \\
\hline $\begin{array}{l}\mathrm{F} \text { test that all } \mathrm{u}_{-} \mathrm{i}=\mathrm{O} \text { : } \\
0.0000\end{array}$ & & & 64 & 8.75 & & Prob $>$ F \\
\hline
\end{tabular}


The FE model was further run Table 3 to appropriately select between the RE and FE.

The Hausman test Table 4 was applied to select the appropriate model between RE and FE.

Table-4. Hausman test results.

\begin{tabular}{|c|c|c|c|c|c|}
\hline & \multicolumn{2}{|c|}{ Coefficients } & \multirow[b]{2}{*}{$\begin{array}{l}\text { (b-B) } \\
\text { Difference } \\
\end{array}$} & \multirow[b]{2}{*}{$\begin{array}{l}\text { sqrt(diag(V_b } \\
\text { V_B) }\end{array}$} & \\
\hline & $\begin{array}{l}\text { (b) } \\
\text { FE1 }\end{array}$ & $\begin{array}{l}\text { (B) } \\
\text { RE1 }\end{array}$ & & & - \\
\hline $\begin{array}{l}\text { Health } \\
\text { Education }\end{array}$ & $\begin{array}{l}.2823343 \\
.0426238\end{array}$ & $\begin{array}{l}.2859859 \\
.0460951\end{array}$ & $\begin{array}{l}-.0036517 \\
-.0034714\end{array}$ & $\begin{array}{l}.0055906 \\
.0013784\end{array}$ & \\
\hline \multicolumn{5}{|c|}{ Test Ho: difference in coefficients not systematic } & \\
\hline \multicolumn{3}{|c|}{$\operatorname{chi} 2(2)=6.68$} & \multicolumn{2}{|c|}{ Prob $>$ chi $2=0.0355$} & \\
\hline
\end{tabular}

Overall, the R-squared statistic indicates that nearly $21.79 \%$ total variation in economic development was accounted for by health and education during the period under review. The $\mathrm{F}(2,64)$ statistic $(=15.45 ; \mathrm{p}<0.05)$ reveals significance of the model; while the interclass correlation reveals that nearly $99.53 \%$ of the variance was due to differences across panels.

\section{CONCLUSION AND RECOMMENDATIONS}

\subsection{Conclusion}

This paper estimated the relative impacts of health and education on economic development. The indication from the results that health has a more pronounced significant positive effect on economic development in the region relative to education provides substantial evidence that health is an effective instrument for development. As such, countries in Southern Africa should invest in expenditures on activities; and provision of social safety nets, whose main goal is to improve, protect and maintain health systems indefinitely. The domains of health systems countries can improve on include nutrition, sanitation, safe and clean water, housing, disease prevention, medical treatment, reduction of premature deaths, providing care for people with chronic diseases, deficiencies, administration of public health care provision and health insurance and health financing mechanisms.

\subsection{Recommendations}

In order to yield more improved and accurate results, future research studies should separate the analysis of the effects health and education on economic development. To begin with, given that health is by itself a broad dimension, future research should compile more elaborate data on health indicators such average survival rates, infant mortality, nutrition, smoking prevalence rates, infectious diseases, health infrastructure and environmental conditions; and estimate their distinct effects on economic development separately from education. Likewise, the analysis of education effects on economic development should be undertaken separately from health; and should incorporate both quantity and quality dimensions of education in order to produce improved results. 


\section{REFERENCES}

Acemoglu, D. and S. Johnson, 2006. Disease and development: The effect of life expectancy on economic growth, NBER Working Paper No. 12269. Available from http://www.nber.org/papers/w 12269.pdf [Accessed May 1, 2014].

Alemu, Z.G., T.L. Roe and R.B.W. Smith, 2005. The impact of HIV on total factor productivity. Number 052, Economic Development Center, University of Minnesota. Available from http://ageconsearch.umn.edu/bitstream/12976/1/edc05-02.pdf [Accessed 30 April, 2014].

Alsan, M., D.E. Bloom and D. Canning, 2006. The effect of population health on foreign direct investment inflows to low-and middle-income countries. World Development, 34(4): 613-630.

Arora, S., 2001. Health human productivity and long-term economic growth. Journal of Economic History, 61(3): 699-749.

Barro, R.J. and J.W. Lee, 2010. A new data set of educational attainment in the world, NBER, National Bureau of Economic Research, Working Paper 15902. Available from http://www.development.wne.uw.edu.pl/uploads/Courses/DW_barrolee_2010.pdf [Accessed May 1, 2014].

Bhargava, A., D.T. Jamison, L.J. Lau and C.J. Murray, 2001. Modeling the effects of health on economic growth. Journal of Health Economics, 20(3): 423-440.

Bloom, D.E. and D. Canning, 2000. Health and wealth of nations. Science, 287(5456): 1207-1209.

Bloom, D.E. and D. Canning, 2005. Health and economic growth: Reconciling the micro and macro evidence, CDDRL Working Paper No. 42. Available from $\underline{\text { http://iis- }}$ db.stanford.edu/pubs/20924/BloomCanning_42.pdf [Accessed 1 May, 20 14].

Bloom, D.E. and D. Canning, 2008. Population health and economic growth. Working Paper No. 24. Commission on Growth and Development. Available from http://siteresources.worldbank.org/EXTPREMNET/Resources/489960$\underline{1338997241035 / \text { Growth_Commission_Working_Paper_24_Population_Health_Economic_Growt }}$ h.pdf [Accessed 30 April, 2014].

Bloom, D.E., D. Canning and J. Sevilla, 2004. The effect of health on economic growth: A production function approach. World Development, 32(1): 1-13.

DSAED, 2010. The role of health in economic development. Available from http://www.aid.govt.nz/sites/default/files/The\%20Role\%20of\%20Health\%20in\%20Economic\%2 oDevelopment.pdf [Accessed 1 May, 2014].

Feinstein, L., R. Sabates, T.M. Anderson, A. Sorhaindo and C. Hammond, 2006. What are the effects of education on health? Available from http://www1.oecd.org/edu/innovationeducation/37425753.pdf [Accessed May 1, 2014].

Fogel, R.W., 2004. Health, nutrition and economic growth. Economic Development and Cultural Change, 52(3): 643-658.

Gallup, J. and J. Sachs, 2001. The economic burden of malaria. American Journal of Tropical Medicine and Hygiene, 64(1-2): 85-96.

Jacobs, P. and J. Rapaport, 2002. The economics of health and medical care. Gaithersburg, MD: Aspen Publishers. 
Kumar, A. and B. Kober, 2012. Education, health, and cross-country productivity differences. Economic Letters, 117(1): 14-17.

Lilliard, L.A. and Y. Weiss, 1997. Uncertain health and survival: Effects on end-of-life consumption. Journal of Business and Economic Statistics, 15(2): 254-268.

Malik, G., 2006. An examination of the relationship between health and economic growth, ICRIER Working Paper No. 185. Available from http://www.icrier.org/pdf/working_paper_185.pdf [Accessed 30 April, 2014].

Mayer, D., 2001. The long term impact of health on economic growth in Latin America. World Development, 29(6): 1025-1033.

Quang, H.V., 2012. Determinants of educational expenditure in vietnam. International Journal of Applied Economics, 9(1): 59-72.

Saha, S., 2013. Impact of health on productivity growth in India. International Journal of Economics, Finance and Management, 2(4): 303-312.

Smith, J.P., 1999. Healthy bodies and thick wallets: The dual relation between health and socioeconomic status. Journal of Economic Perspectives, 13: 145-166.

Stark, O. and M.R. Rosenzweig, 2006. Handbook of population and family economics. North Holland: Elsevier.

Stevens, P. and M. Weale, 2003. Education and economic growth. National Institute of Economic and Social Research. Available from http://cee.lse.ac.uk/conference_papers/28_11_2003/martin_weale.pdf [Accessed 1 May 2014].

Weil, D.N., 2006. Accounting for the effect of health on economic growth. NBER Working Paper No. 11455.

World Bank, 1993. World development report 1993: Investing in health. Washington, D.C.: World Bank and Oxford University Press.

World Health Organisation, 2002. Health, economic growth and poverty reduction. Available from http://whqlibdoc.who.int/publications/9241590092.pdf [Accessed 1 May, 2014].

World Health Organisation, 2003. WHO definition of health. Available from http://www.who.int/about/definition/en/print.html [Accessed 1 May, 2014]. 